Poznańskie Studia Teologiczne 27(2013), s. 69-79.

Emery de Gaál

University of St. Mary of the Lake

Mundelein Chicago

\title{
Pope Benedict XVI and humanity's quest for genuine peace. The christocentric response
}

In 1980 then archbishop of Munich, Joseph Cardinal Ratzinger visited with an official delegation of the German bishop's conference his Polish brother bishops. In venerable Wawel Cathedral in Cracow, in a Poland then still under the rule of a communist dictatorship, Cardinal Ratzinger delivered a memorable homily titled "True Peace and true Culture: Christian Faith and Europe". ${ }^{1}$ In this eminently historic location he argued the gift of peace requires of people forgiveness and a keen sense of brotherhood arising from faith. ${ }^{2}$ It is when man renders God the glory due Him, that he, man, becomes capable of honoring also his fellow human beings. "The grand cathedrals are also nowadays oases of humanity, of human dignity, precisely because they are spaces of God's honor publicly acknowledged". ${ }^{3}$ He elaborated in this mediation that "Christian faith is a culture of brotherly love, a culture of mercy, and precisely for this reason a culture of social justice". ${ }^{4}$ In closing he prayed that Our Lady "may guide us to a genuine peace in the faith and to genuine culture". ${ }^{5}$

In Assisi, on October 27 2011 Pope Benedict XVI repeated Bl. Pope John Paul II's memorable initiative in favor of peace in 1986. It was placed under the official theme "Pilgrims of Truth, Pilgrims of Peace". As in Cracow in 1980, so again in Assisi in 2011, in the presence of the precious spiritual heritage of St. Francis of Assisi, il Poverello, and 300 hundred representatives of religions the world over, he correlates the truth of man with man's ability to establish peace. Religion is the guardian of such truth. Yet, with a sense of shame the pope acknowledges that "Christian faith" was often abused to justify war. This notwithstanding, he underlines: all should be mindful that without religion there is no objective criterion for judging war and violence as evil. Far from legitimizing

\footnotetext{
${ }^{1}$ J. Ratzinger, Wahrer Friede und wahre Kultur: Christilischer Glaube und Europa, in: Ibid., Christilischer Glaube und Europa, 12 Predigten, München 1981, p. 7-18.

${ }^{2}$ Ibid., p. 7-8.

${ }^{3}$ Ibid., p. 13.

${ }^{4}$ Ibid., p. 15.

${ }^{5}$ Ibid., p. 18.
} 
violence, it is "the true nature of religion" to preserve the truth of God and man. The supreme Pontiff states unequivocally: "For us the Cross of Christ is the sig of the God put 'suffering with (compassion) and 'loving with' in place of force. His name is 'God of love and peace' (2 Cor 13:11)." The denial of God invariably leads to a blind cul de sac, to a lack of orientation, to untold horror and to "the worship of mammon, possessions and power". In short, he argues "the absence of God leads to a decline of man and humanity". ${ }^{6}$

\section{The Pope and Bishops: Representing Christ's Peace}

Far from a rapid platitude, the frequent use of the term "peace" is a constitutive element of Catholic - and more generally Christian - rhetoric from its very beginnings two thousand years ago, but traces its roots well back to the earliest Judeo-Christian Old Testament times and to Semitic culture in general.

From early Christianity onward every bishop and only the bishop greets the liturgical assembly of faithful with the words pax vobiscum - "peace be with you". It is wish these very words that Our Risen lord appeared to the frightened and conflicted flock of disciples on the evening of Easter Sunday (John 20:19). "In this word of peace he wipes away, so to speak with a gentle but equally strong gesture the fear darkening the hearts of his (followers)". J Jesus Christ is the source of peace in the Christian understanding. As Vicar of Christ, the preeminent Catholic bishop, the bishop of Rome and pope of the universal Church, heightens the world's awareness of the central role this term plays for religion in general and specifically for the Catholic faith. Yet, the genuinely Christian understanding of peace is not always appreciated.

\section{The Quest for Peace has a Name: Benedict}

It is difficult to imagine a pontiff more eloquently enunciating the Christian message of peace than Pope Benedict XVI. This is clear from the first day of his pontificate. He chose as name that of his predecessor Pope Benedict XV (1914-1922). Benedict XV had been a committed and neutral advocate for the cause of peace throughout the carnage of World War I (1914-1918), going down in history as "the Pope of Peace". In his first message on the occasion of World Peace Day 2006 In Truth, Peace (lies) Pope Benedict XVI confirmed this interpretation

\footnotetext{
${ }^{6}$ See: www.chiesa.espressonline.it [accessed October $28^{\text {th }}, 2011$ ].

${ }^{7}$ Kardinal J. Ratzinger, Geduld des Wachsens und Reifens, Erstes Hirtenwort des Erzbischofs von München und Freising, Kardinal Joseph Ratzinger, and die Gemeinden des Erzbistums, in: "L'Osservatore Romano" nos. 30-31 (July 29, 1977), p. 13.
} 
of his name. "In taking this name, I wanted to invoke both the Patron Saint of Europe, who inspired a civilization of peace on the whole continent, and Pope Benedict XV... who worked for a universal acknowledgement of the lofty demands of peace". 8

A few days after his enthronement, in his first circular letter Ubi primum Pope Benedict XV exhorted in drastic words all warring parties. On July 28, 1915 he described war as "a horrendous butchery" (orrenda carneficina). He launched various peace initiatives during the Great War. In addition, the present pontiff feels a spiritual and historic affinity to the founder of Western monasticism, S. Benedict of Nursia (ca. 480-ca. 550). The monk and abbot Benedict, Patron of Europe, is considered the spiritual father of a European civilization fostering peace. The Latin origin of the name Benedict is Benedictus. This compound traces its etymological roots to the term bene dicere, to bless.

\section{Religions' Commission to promote Peace: Reason, Conscience and Justice}

Pope Benedict supplies a pioneering stimulus for interreligious dialogue. Especially in his famous, but little understood Regensburg Address, ${ }^{9}$ he expresses his firm belief in the reciprocally beneficial relationship between faith and reason. Instead of equalizing all religious creeds and advancing a superimposed project called "world ethos", Pope Benedict postulated already in 2004 during ceremonies commemorating the $60^{\text {th }}$ anniversary of the landing of allied forces in Normandy in 1944 the programmatic formula: "without peace between reason and faith there is no world peace". ${ }^{10}$

On the topic of religions' contribution to peace the then prefect of the Congregation for the Doctrine of the Faith spoke at the fifth Christian-Muslim Consultation convened at the Orthodox center in Chambésy, Switzerland in 1988. ${ }^{11}$ Again, here he is careful to establish in a normative way a direct correlation between peace and justice on the one hand and on the other to deny "pure reason" à la Immanuel Kant (1724-1804) as sufficiently competent to determine the con-

${ }^{8}$ Pope Benedict XVI, In Truth, Peace. Message for the 2006 World Day of Peace 1 January, 2006. See: www.vatican.va [accessed October 10 $10^{\text {th }}$, 2011].

${ }^{9}$ Pope Benedict XVI, "Faith, Reason and the University", lecture held at the Aula Magna of Regensburg University, Germany on September 12, 2006. See: www.vatican.va [accessed October $\left.18^{\text {th }}, 2011\right]$.

${ }^{10}$ J. Ratzinger, Values in Time of Upheaval, (New York: Crossroad, 2006), p. 108. Cf. H. Hoping, Die anstößige Wahrheit des Glaubens: das theologische Profil Joseph Ratzingers, (Freiburg i. Br.: Herder, 2005), p. 18.

${ }^{11}$ J. Ratzinger, Der Auftrag der Religion angesichts der gegenwartigen Krise von Frieden und Gerechtigkeit, "Communio" 18(1989), pp. 113-122. The conference had been held December 12-15, 1988. 
tent and scope of what the true constituents of peace are. No matter how limited and culturally relative human insight into the nature of peace is, it is the Christian religion that can lead to genuine insight.

All human beings might agree that "(a) loss of a common understanding of justice" leads to a loss of peace. This may be caused by a government, by a liberation movement or by a terrorist group severing ties with justice. It destroys peace from within the political order. Just as later in his memorable speech in the German diet on September 22 ${ }^{\text {nd }}, 2011$, he draws on St. Augustine's famous rhetorical question: "is not a state without justice (but) a band of robbers"? ${ }^{12}$ Even while it might not always wage war or inflict harm on its populace, a state lacking an appreciation for the inviolable nature of justice is supremely inimical to peace since it is inclined to reducing justice to what is advantageous for a particular interest group. Ratzinger cite as cases in point Hitler's Third Reich and Stalin's regime. He soberly observes "Viewed from outside there may be peace, but it is the peace of a cemetery". ${ }^{13}$ At this phase of the argument Ratzinger refers to the Russian philosopher Vladimir Solovyov's (1853-1900) famous fictional figure to illustrate the beguiling but in the final analysis, fatal nature of an immanentist understanding of peace: the nullifidian Antichrist, far from being an author of global peace and progress, in fact dehumanizes the world. ${ }^{14}$

If justice possesses no universally recognized value, then the qualitative difference between justice and injustice fades and arbitrariness asserts itself, resulting in the cruel homo, homini lupus - "man becoming a wolf unto man". By recourse to the pre-Christian philosopher Socrates (ca. 470-399 BC), ${ }^{15}$ Ratzinger upholds the inherent and inviolable value of justice and rejects Thomas Hobbes' (1588-1679) infamous and deeply cynical observation: authoritas non veritas facit legem - "authority, not truth establishes law". ${ }^{16}$ The public realm must nor subscribe to legal positivism as advanced by Hans Kelsen (1881-1973), lest it become the market for constantly warring particularisms - the bonum commune, the common good of all is lost sight of. He faults Kant for not rising above a merely utilitarian explanation of the term justice in his treatise on perpetual Peace. ${ }^{17}$ Neither authority, nor egoism, nor utility suffice in establishing the bases for justice and peace. The body politic needs to be cognizant of the fact that

\footnotetext{
${ }^{12}$ Augustinus, De Civitate Dei, IV, 4. Corpus Christianorum Latinorum XLVII, p. 101. "Remota itaque iustitia quid sunt regna nisi magna latrocinia?" Apart from Augustine, he is indebted on this point to H. Kuhn, Der Staat. Eine philosophische Darstellung, München 1967.

${ }_{13}$ J. Ratzinger, Der Auftrag der Religion, p. 116.

${ }^{14}$ Ibid. Ratzinger cites J. Pieper, Über das Ende der Zeit. Eine geschichtsphilosophische Betrachtung, München 1980, $3^{\text {rd }}$ ed., pp. 113-136. V. Solovyov, The Antichrist, Edinburgh 1982.

${ }^{15}$ R. Guardini, Der Tod des Socrates, Mainz - Paderborn 1987.

${ }^{16}$ Latin translation of Leviathan (1651), T. Hobbes, Opera philosophiae quae latine scripsi omnia, ed. W. Molesworth, vol. III, London - Bonn 1841, c. XXVI, p. 202.

${ }^{17}$ I. Kant, Perpetual Peace, B 65, 66.
} 
natural law and human rights precede materially and undergird any form of positive law legislated by a state. Ratzinger apodictically concludes:

"there is no justification for law without transcendence. Wherever God and the basic form of human existence established by him are suppressed in public consciousness and pushed into the private sphere, into the merely subjective, (there) the term law dissolves and thereby (also) the foundation of peace (suffers irreparable damage)". ${ }^{18}$

He reminds his audience that peace requires a metaphysical foundation no political or secular discourse can provide or replace. Only religion can supply it. However, he hastens to add that the Church needs also to be mindful of both how it can promote peace and what it neither can nor may do in this regard. Religion incessantly reminds us of the human person as the source of truth far surpassing the merely immanent and ephemeral. Thereby, when confronted with a concrete situation, he is capable of correlating justice, utility, authority and truth. But man does not generate truth on his own. As "an educator" the Church liberated man from "the prison of positivism" and opens him to "truth, God and the power of conscience". Every religion assists man and society in the cultivation of a healthy conscience. It precludes simply following uncritically majority opinions and reminds people to follow the dictate of the pre-given, never self-generated conscience. ${ }^{19}$ In agreement with the noted German psychologist Albert Gorres (1918-1996), he postulates that the ability to admit guilt belongs constitutively to the good and sound "psychological makeup" of a human person. ${ }^{20}$ Without it he loses his emotional and spiritual balance; he then must be linked to "a living corpse, a theatrical mask. ${ }^{21}$ "

A reign of terror is on of lie. It darkens the conscience; and this almost invariably begets strife and war. In order to rid society from such a darkening o the conscience and perversion of law, a bellum iustum, a just war may be called for. A just war, as waged or instance by the allies during Second World War, restores justice and the rule of conscience. Immediately after World War II Christian politicians, such as Churchill, de Gasperi, Adenauer and Schumann laid the foundations for a historically unparalleled period of peace in Western Europe. Turning to religion as the indispensable basis for human conduct, they deliberately attempted to cancel out ideological tyranny which deforms human reason. ${ }^{22}$

${ }^{18}$ J. Ratzinger, Der Auftrag der Religion, p. 119.

${ }^{19} \mathrm{~J}$. Ratzinger, Values in a Time of Upheaval, pp. 75-76.

${ }^{20}$ „Zum seelischen Haushalt des Menschen wesentlisch gehört”. J. Ratzinger, Values in Time of Upheaval, p. 80.

${ }^{21}$ Ibid. quoting A. Görres, Schuld and Schuldgefühle, "Communio" 13(1984), pp. 430-443, at p. 434.

22 J. Ratzinger, Values in Time of Upheaval, pp. 101-102. 
Memorably, also on the beaches of Normandy Ratzinger warned of two extremes: there is equally the danger of "a pathology of religion and a pathology of reason". Faith and reason must constantly be brought into a mutually beneficial relationship with each other. He contends only such a correlation equilibrium provides a universally convincing basis for human rights. As the thoughts of the French thinker Jacques Derrida (1930-2004) illustrate, human reason left to its own empirical devices becomes self-corrosive. In a society subscribing to the principle of living etsi Deus non daretur (as if God did not exist) "human conduct gets lost in indeterminacy and becomes the hopeless prey of the forces of evil". ${ }^{23}$ Religions together have the moral responsibility to bear witness to God's existence. Christian belief in a creating God - all the more who is the Logos entails trusting in the power of human reason. ${ }^{24}$ Confronted with post-Enlightement rationality, Ratzinger sees only recourse to the God of Scripture and the God of Jesus Christ as bringing back into the path of peace. ${ }^{25}$

\section{The Task of the Church}

The topic of the "Washing away guilt" is not specific to one particular religion. It expresses a universal longing by all human beings for reconciliation and peace. In order to underline this Ratzinger quotes a phrase the Greek poet Aeschylus (525-456 BC) had coined in this context. ${ }^{26}$ When such purification occurs, then our being is transformed beyond our own capacities. This is the novelty of Christianity. The logos, the second person of the Blessed Trinity, Jesus Christ becomes the definitive atonement and expiation of human guilt. In Him transfiguring forgiveness occurs beyond all human expectation and imagination.

Nevertheless, the Church does not possess "a specific illumination as regards particular political questions. It must not present itself as the sole bearer of political reason. It shows reason paths, but (political reason's) own responsibility remains". ${ }^{27}$ The Church does far more than simply supplying the bases for a peaceful state of affairs. It brings to bear something secular rationality can never achieve: the works of charity serving the poor, he ailing, the lost and the oppressed. "In the zones of strife, which have always existed and will always exist, (the Church) provides the power of survival and along with it the ability to for-

${ }^{23}$ In this regard Ratzinger is indebted to L. Kolakowski, Religion - if there is no God, New York 1982. Cf. J. Ratzinger, Values in Time of Upheaval, p. 111.

${ }^{24}$ J. Ratzinger, Values in Time of Upheaval, p. 112.

${ }^{25}$ J. Ratzinger, Values in Time of Upheaval, pp. 115-116.

${ }^{26}$ Aeschylus, The Eumenides, 280-281.

${ }^{27}$ J. Ratzinger, Der Auftrag der Religion, p. 121. 
give, the ability to awaken a new beginning. Only who is capable of forgiving, can build and preserve peace". ${ }^{28}$

This evidences the indispensable role of religion for a peaceful future of the global human family. Equally it describes the limitations of religion. The Church cannot impose or enforce peace as it lacks Our Lord' specific authorization for such a task. He cautions that anything else smacks of the third temptation of Jesus by the devil: "All these I will give you, if you (only) will fall down and worship me" (Mt 4:9). However worth striving for, world peace is not the ultimate goal of human existence. Therefore, Church is not "a political action group", but, he argues, quoting the Greek Orthodox Metropolitan Damaskinos Papandreou (1939-2011) "a witness to charity ready for martyrdom". ${ }^{29}$ This is the manner Christianity collaborates with other religions in bringing about peace.

\section{The Christocentric Understanding of Peace}

After taking possession of his archdiocese Munich-Freising in 1977 amid the turmoil of the peace movement preoccupying Western society, then archbishop Ratzinger issued a pastoral letter titled "The Patience of Growth and Maturing" dated June 7, 1977..$^{30}$ There he reiterates that the peace the risen Lord imparts on us human beings is far more than human efforts left to their own resources could ever bring about. Neither can human beings defeat on their own, nor can they push open the gates to the eternal Thou of God.

"But he (the Lord) does not condemn us to idleness; the Lord's peace requires that we draw to the mind frame of Jesus Christ". Ratzinger argues peace is not an abstract philosophical term describing the thinker's relationship to the primordial ground of being or a juridical category defining a state of non-belligerence between nations, but - unbeknownst to the majority of humankind - a tangible person - equally divine and human: Jesus Christ. In order to gain access to such peace we must shed fear and vainglory. The newly appointed archbishop cautions: "the slogan 'be kind to one another' need not be disparaged, but it does not reach the height of the gospel and thereby to a true encounter with one another". In his estimation a line from Our Lord's Prayer is of central importance for understanding the full nature of peace: "Thy will be done, on earth as it is in

\footnotetext{
${ }^{28}$ J. Ratzinger, Der Auftrag der Religion, p. 121. For this section see also Pope Benedict XVI's first encyclical Deus caritas est, nos. 3 ff.

${ }^{29}$ J. Ratzinger, Der Auftrag der Religion, p. 122. Cfr. Metropolite Damaskinos Papandreou, Contribution de l'Église orthodoxe à la réalisation des ideaux chrétiens de paix, de liberté, de fraternité et d'amour entre les peuples, et la suppression des discriminations raciales, in: Weisheit Gottes - Weisheit der Welt, FS J. Ratzinger, vol. II, St. Ottilien 1987, pp. 1333-1343, at pp. 1342f.

${ }^{30}$ J. Ratzinger, Geduld des Wachsens und Reifens, op. cit.
} 
heaven" (Mt 6:10). The terrestrial kingdom of God is where God's will is being fulfilled. Full peace ultimately requires on our part seeking truth and imitating, emulating Jesus Christ, yes conjoining our fates with the earthly fate of the Godman. Constant purification and self-correction are indispensable prerequisites for doing God's will and thereby laboring for peace. ${ }^{31}$

The atonement effected once and for all times by Jesus Christ creates peace. The blood that Jesus shed does not call for retribution, but enables reconciliation - so, the Letter to the Hebrews argues (Heb 12:24). The Letter to the Ephesians concurs a fortiori. Jesus Chris is our peace. As he persevered in charity despite suffering death, he brings together all peoples.

"For he is our peace, who has made us both one, and has broken down the dividing wall of hostility, by abolishing in his flesh the law of the commandments and ordinances that he might create in himself one new man in place of the two, so making peace, and might reconcile us both to God in one body through the cross, thereby bringing the hostility to an end. And he came and preached peace to you who were far off and peace and preached peace to you who were far off and peace to those who were neat; for through him we both have access in one Spirit to the Father. So then you are no longer strangers and sojourners, but you are fellow citizens with the saints and members of the household of god, built upon the foundation of the apostles and prophets, Christ Jesus himself being the cornerstone in whom the whole structure is jointed together and grows into a holy temple in the Lord; in whom you are built into it for a dwelling place of God in the Spirit" (Eph 2:14-22).

Christ's peace transcends all boundaries. The realization of this central fact must determine our actions. It invites us to promote the forces of the good and awakens our freedom to do the ethically good- and to confidently "oppose the freedom of evil". ${ }^{32}$

\section{Belief in the Triune God and Peace - its eschatological Reservation}

All religions live under the difference of good and evil. Antiquity was preoccupied with the presence of frightening powers and the need to placate a plethora of deities perceived at times as vengeful. Christianity unmasks such a world as hollow. Paul declares to this intimidated world: "We know that 'an idol has no real existence', and that 'there is no God but one' ... For although there may be so-called 'gods' and many 'lords' - yet there is one God, the Father" (1 Cor 8:5f).

\footnotetext{
${ }^{31}$ Ibid. Cf. J. Ratzinger, Behold the Pierced One. An Approach to a Spiritual Christology, San Francisco 1987.

32 J. Ratzinger, Values in Time of Upheaval, p. 121.
} 
With Jesus the reconciler of humankind ascended into heaven. It is henceforth the task of the Holy Spirit, also called the "Paraclete" in Greek or "comforter" in English, to abide with us. This realization has the Apostle Paul state confidently that henceforth in Jesus Christ humankind is granted access to the front of being (Rom 8:31-39).

In a homily in aged-old Norman-Romanesque Bayeux Cathedral commemorating the allied landing in Normandy the theologian Ratzinger speaks on The Triune God and Peace in the World. During the sermon he makes reference to the celebrated icon by the Russian painter Andrei Rublev (ca. 1360-1430) depicting the Blessed Trinity (The Old Testament Trinity, ca. 1410): the visit of the three men (angels) with Abraham and Sara at the oaks of Mamre (Gen 18:1-33). Abraham quickly realizes that these are not common men and worships in these three divine unity. Pope Benedict alerts the international congregation that here a wondrous event makes present on earth the mystery of the divine Godhead as triune charity - the perfect image of peace. The artist unites the trees into one, to that of the cross as the expression of triune self-giving, which ever again becomes present in the Eucharist. ${ }^{33}$ Thus the Eucharist is seen as both the justification for and the deepest source of peace in the world, yet always referring to an ultimate peace outside and beyond itself.

\section{Assessment}

Grounded in the natural law tradition of Catholic faith, Pope Benedict XVI is capable of demonstrating the relevance of both religions in general and of Christianity in particular for establishing a common will among people to promote peace. With an aversion against Neo-Scholasticism ever since he was seminarian, Ratzinger never wrote on the Thomist topic of nature and grace. Nonetheless, he is acutely mindful of the fact that the world is missing something essential to its own well-being without reference to religion and the numinous. The secular, liberal state embraces values, such as human rights, truth, free speech, etc. without being able to supply the moral or intellectual bases for these as it cannot generate the requisite metaphysical truths. ${ }^{34}$

\footnotetext{
${ }^{33}$ J. Ratzinger, Values in Time of Upheaval, pp. 161-167. Cf. P. Evdokimov, L'Art de l'icône. Théologie de Beauté, Paris 1970, p. 208.

${ }^{34}$ Named after a former judge on the German constitutional court Böckenförde, it is known as the Böckenförde-Dictum or - Dilemma. Die freiheitlische säkularisierte Staat lebt von Voraussetzungen die er selbst nich garantieren kann. Das ist das große Wagnis das er um der Freiheit willen eingegangen ist. Als freiheitlicher Staat kann er einerseits nur bestehen wenn sich die Freiheit die er seinen Bürgern gewährt von innen her aus der moralischen Substanz des einzelnen und der Homogenität der Gesellschaft regulliert. Anderseits kann er diese inneren Regulierungskräfte nicht von sich aus das heißt mit den Mitteln des Rechts - zwanges und autoritativen Gebots zu garantieren
} 
This calls for and justifies in his judgment "maintaining tensions" between two poles: such as faith and reason, Church and state, etc. Both realities in such a polarity profit from it. This principle of maintaining tensions it a salient element of Catholic theology. Modern theologians have embraced it: Johann Adam Mohler (1796-1838), Bl. John Henry Newman (1801-1890) and the late Cardinal Avery Dulles, SJ (1918-2008), to mention but a few representatives. ${ }^{35}$ But this principle of Catholic theology may be traced back to early Christianity. Pope Gelasius I (492-496) had insisted of two realms enjoying equal authority in the world: the imperium and the sacerdotium, the state and the Church. ${ }^{36}$

Along with the New Testament Ratzinger knows that eirene ultimately is a theological category identical with a peace only faith can access: eternal life. Thus even the kingdom of God on earth, the Church, becomes merely a proleptic realization of peace. Being Christian means being a peacemaker. Yet, Ratzinger warns against the danger of Millenarianism which advocated an imminent new age of peace, i.e. an immanentist understanding of peace. The New Testament had denounced false forms of peace (Mt 10:34; Lk 12:51). Ratzinger's position is all the more comprehensible as he had discovered still as student in his Habilitationsschrift that St. Bonaventure (ca. 1217-1274) had argued against the Chiliarist views of Joachim of Fiore (ca. 1135-1202).$^{37}$ Along with the African Church Father Augustine (354-430), the subject of his doctoral dissertation, he is acutely aware that pax also mans what properly ordered moral action can achieve on earth. ${ }^{38}$ Nevertheless, there remains an unbridgeable qualitative difference, an eschatological reservation for Augustine between the pax of the Civitas Dei, the City of God and the pax of the civitas terrena, the earthly city. Exclusively heaven is a state of eternal life in peace. ${ }^{39}$ Sub specie aeternitatis Christians and all religions are called to labor for peace on earth by developing and forming consciences in people, advocating justice and subjecting all matters to rational judg-

versuchen ohne seine Freiheitlichkeit aufzugeben und - auf säkularisierter Ebene - in jenen Totalitätsanspruch zurückzufallen aus dem er in den konfessionellen Bürgerkriegen herausgeführt hat". E.W. Böckenförde, Staat, Gesellschaft, Freiheit, Frankfurt am Main 1976, p. 60 (italics added). Ibid., State, Society and Liberty: studies in political theory and constitutional law, New York 1991. Cf. J. Ratzinger, J. Habermas, The Dialectics ad Secularization: one Reason ad Religion, San Francisco 2006, p. $55 \mathrm{ff}$.

${ }_{35}$ A. Dulles, John Henry Newman, New York 2002, p. 112.

${ }^{36}$ Cf. Pope Gelasius I, "Famuli vestrae pietatis" ad Imp. Anastasium. This famous letter is dated 494 and addressed to the East Roman Emperor Anastasius I. DH 347.

37 J. Ratzinger, Die Geschichtstheologie des heiligen Bonaventura, München - Zürich 1959. Reprint: J. Ratzinger, Die Geschichtstheologie des Heiligen Bonaventura, St. Ottilien 1992, with new foreword.

${ }^{38}$ J. Ratzinger, Volk und Haus Gottes in augustinus Lehre von der Kirche, München 1954. Reprint: J. Ratzinger, Volk und Haus Gottes in Augustinus Lehre von der Kirche, St. Ottilien 1992 with new foreword.

${ }^{39}$ Augustinus, De Civitate Dei, lib. XIX, cap. 11-27. PL 41, coll. 638-658. 
ment. This establishes the crucial link between faith and reason. All this comes about only if reason remains mindful of its limitations. Rationality on its own neither provides the basis for human dignity nor can it inspire human behavior. For this it needs always to refer to religion. In continuation with Catholic teaching, and especially in agreement the Church Father Augustine, but also in deliberate demarcation from Liberation Theology or the peace movement en vogue in the last decades of the $20^{\text {th }}$ century, the theologian Ratzinger is careful to retain a Christian and eschatological definition of peace the defies facile human comprehension but is grounded in the ineffable nature of the one and triune God.

As all great and classical theologians, Pope Benedict XVI is thoroughly Trinitarian in his approach. This he shares with such luminaries on the theological firmament of the $20^{\text {th }}$ century as Karl Rahner (1904-1984), Hans Urs von Balthasar (1905-1988), Karl Barth (1886-1968) and Dumitru Staniloae (1903-1993). Peace in its most comprehensive meaning is the state describing the dynamic reality of the Blessed Trinity. It becomes somehow apparent to earthly, spirit-gifted existence in the incarnation of the second person of the Blessed Trinity, in the figure of the God-man Jesus Christ alone.

\section{Papież Benedykt XVI a poszukiwanie prawdziwego pokoju. Odpowiedź chrystocentryczna}

\section{Streszczenie}

Artykuł przedstawia inicjatywy na rzecz pokoju Benedykta XVI, który nie tylko jawi się jako kontynuator zamierzeń Jana Pawła II, lecz również jako ten, który wprowadził pewne nowe elementy. Papież w swoim nauczaniu nie tylko zwrócił uwagę na warunki służące budowaniu prawdziwego pokoju (sprawiedliwość, poszanowanie dobra wspólnego), lecz również wyznaczył Kościołowi zadania, mające służyć tej sprawie. Artykuł prezentuje teologiczną interpretację kwestii pokoju w świetle tajemnicy Chrystusa.

\section{Słowa kluczowe}

Benedykt XVI, nauczanie, pokój, Chrystus, ludzkość

\section{Keywords}

Benedict XVI, Teaching, Peace, Christ, Humanity 